\title{
Transforming the Chinese Economy
}

\author{
Edited by \\ CAar Fang
}

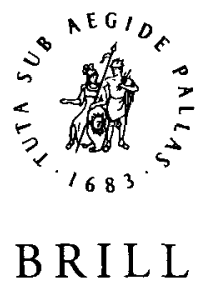

LEIDEN - BOSTON

2010 


\section{CONTENTS}

List of Figures ….............................................................. vii

List of Tables ….............................................................. ix

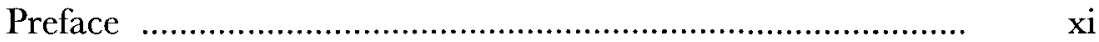

Cai Fang

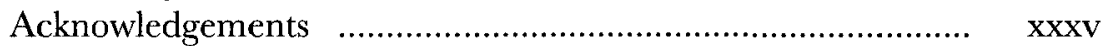

List of Contributors ........................................................... xxxvii

Chapter One Formation of China's Rural Reform Policy 1 Chen Xiwen

Chapter Two The Reform, Opening, and Development of China's Industrial Economy

Chen Jiagui and Wang Qin

Chapter Three Labor Market Development and Expansion of Rural and Urban Employment ...................................... Cai Fang

Chapter Four The Intrinsic Logic of China's Banking Industry Reform Yi Gang

Chapter Five Government Transformation and Public Finance

Hu Angang

Chapter Six China's Integration with the World:

Development as a Process of Learning and Industrial

Upgrading

Justin Yifu Lin and Yan Wang

Chapter Seven Beyond the East Asian Miracle: Looking Back and Future-Prospects for China's Economic Growth Model 
Chapter Eight Economic Growth and Income Distribution: An Empirical Analysis of China's Experiences Li Shi

Chapter Nine Women's Contribution to Economic Development: Thirty Years of Rural Labor Market Development and Women's Participation and Contribution

Linxiu Zhang and Team 